\title{
PALEOMAGNETISM AND GEOCHRONOLOGY OF THE PLIOCENE-PLEISTOGENE LAVAS IN ICELAND
}

\author{
Ian MCDOUGALL \\ Department of Geophysics and Geochemistry, Australian National University, \\ Canberra, A.C.T., Australia \\ H. WENSINK \\ Geologisch Instituut der Rijksuniversiteit te Utrecht, Utrecht, The Netherlands
}

Received 21 June 1966

\begin{abstract}
Potassium-argon dates are reported on five basalt samples from the Pliocene-Pleistocene sequence of lavas in the Jokuldalur area, northeastern Iceland. These dates confirm the correlations previously made with the geological time scale by means of paleomagnetic stratigraphy. The R1 and N2 polarity epochs are shown to be equivalent to the Matuyama reversed and Gauss normal polarity epochs respectively. Within the N2 (Gauss) normal epoch up to three successive lava flows occur which are reversely magnetized. Dating of a normally magnetized basalt immediately below these reversed lavas gives a result of $3.10 \pm 0.10 \mathrm{~m} . \mathrm{y}$., and confirms the reality of the Mammoth reversed event, first recognized in California. Two intercalations of normally magnetized lavas occur in the R1 (Matuyama) reversed epoch. The older of the normal flows may represent the Olduvai event; the younger normal polarity flow has been dated at $1.60 \pm 0.05 \mathrm{~m} . \mathrm{y}$., and possibly indicates the presence of yet another normal event in the Matuyama reversed epoch. We propose the name Gilsa for this possible additional event.

Immediately above the basalt dated at $3.10 \pm 0.10 \mathrm{~m} . \mathrm{y}$. occurs a tillite, which suggests that regional glaciation commenced in Iceland at about this time. Hence, the base of the Pleistocene may be as old as $3 \mathrm{~m} . \mathrm{y}$.
\end{abstract}

\section{INTRODUCTION}

Iceland is situated at about $65^{\circ} \mathrm{N}$ latitude on the Mid-Atlantic Ridge. The island is built mainly of basaltic lavas that range in age from Lower Tertiary to the present time. A main subdivision is made between the older Plateau Basalt Series and the younger Pliocene-Pleistocene Graue Stufe or Grey Phase [1]. Structurally Iceland may be divided into three units: a western and eastern horst, which are separated by a central graben. The Graue Stufe, the series with which we are concerned, is best exposed adjacent to this tectonic depression.

In a volcanic region such as Iceland, where fossils are rare, a stratigraphy based on reversals of the geomagnetic field has enabled correlation of the Graue Stufe sequences from one area to another [2-5]. These workers also have extended correlations to the geological time scale by comparison with a paleomagnetic stratigraphy established elsewhere. From paleomagnetic measurements and $\mathrm{K}$-Ar age determinations on rocks from a number of widely distributed regions throughout the world a remarkably consistent paleomagnetic stratigraphy has emerged [6-8].

To add to the available data on age versus magnetic polarity, and to determine whether correlations with the geological time scale are correct, we have made $\mathrm{K}-\mathrm{Ar}$ isotopic age measurements on samples from a section of the Graue Stufe in the Jökuldalur area of northeast Iceland. Our results also have some bearing on the age of the Pliocene-Pleistocene boundary.

\section{PALEOMAGNETIC MEASUREMENTS}

A simplified section of the Graue Stufe sequence in the Jokuldalur area is given in fig. 1. Oriented samples were collected at intervals through the section and paleomagnetic measurements were made. The results are given in detail by Wensink $[5,9]$; they will only briefly be reviewed here. Over a wide area there is a consistent paleomagnetic stratigraphy which provides strong evidence that the directions of magnetization reflect the polarity of the ambient geomagnetic field rather than being caused by self-reversal mechanisms. 


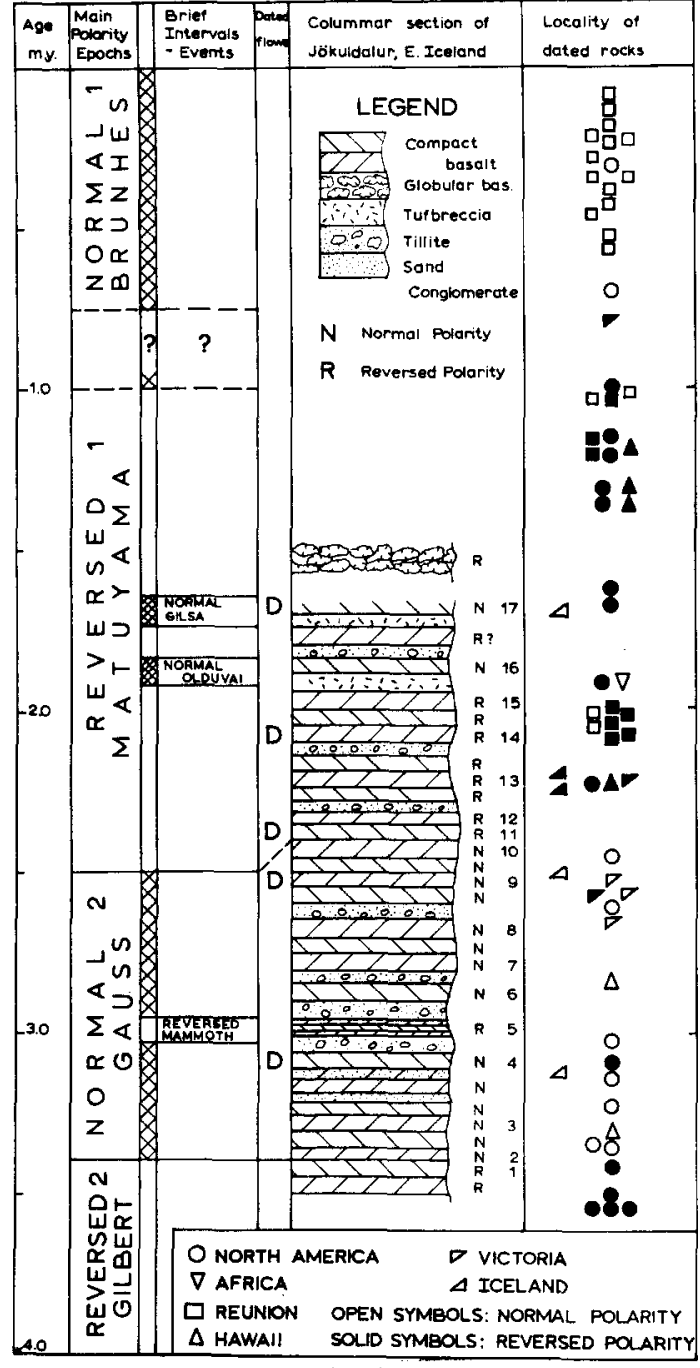

Fig. 1.

Near the rim of the central graben in the Jokuldalur area occur a few basalt lava flows assigned to the present paleomagnetic normal polarity period, the N1 epoch, or, in terms of the nomenclature of Cox et al. [10], the Bruhnes epoch. Below these lavas occur basalts assigned to the R1 (Matuyama) and the N2 (Gauss) epochs. They in turn overlie older basalts. Apart from the relatively long polarity epochs, each of which is represented by thick piles of lavas, shorter periods, called events, are found in which the polarity is opposite to that of the main epoch. Thus within the N2 normal epoch occur three successive lavas which have reversed remanent magnetization, and similarly within the R1 epoch two intercalations of normally magnetized flows are observed. These short intervals of opposite polarity also appear to be caused by changes in polarity of the geomagnetic field rather than by self-reversal of magnetization.

Demagnetization experiments on the samples used in this study indicate that the remanent magnetization is stable [5]. The pole positions calculated from the mean directions of the individual lava flows reveal quite a large dispersion that may represent moments of the secular variation of the geomagnetic field [5]. However, combining all the data from both the normal and reversed lavas and disregarding sign, the calculated pole position differs little from the rotation axis of the earth.

\section{ISOTOPIC AGE MEASUREMENTS}

The basalts of the Graue Stufe sequence in the Jokuldalur area are mainly oceanic tholeiites. Because of their characteristically low potassium content and because some of the rocks are deuterically altered, considerable difficulties were encountered in obtaining precise and accurate $\mathrm{K}-\mathrm{Ar}$ dates on these samples. The dating techniques used were described previously [11]. Whole rock samples were employed; argon was measured by isotope dilution and potassium by flame photometry. Results are given in table 1; the position of each sample in the sequence and comparisons with polarity and age results from elsewhere are shown in fig. 1. Estimates of the precision of the dates are given in table 1 ; they are controlled in most cases by the small proportion of radiogenic argon found. Brief petrographic descriptions of the samples are given in the appendix. Samples from all but one of the lava flows measured paleomagnetically were available for the dating, but more than half of these were rejected because of excessive deuteric alteration.

The dating results amply confirm that the R1 and N2 polarity epochs in this region of Iceland are equivalent to the Matuyama and Gauss epochs respectively, as has been inferred by Rutten and Wensink [3] and Wensink [9].

A sample from the normally magnetized flow 4 (fig. 1) was the stratigraphically lowest rock in the sequence that was suitable for dating. This lava was unaltered and holocrystalline, except for a few per cent of isotropic glass, and hence is believed to be ideal for dating. The measured date of $3.10 \pm 0.1 \mathrm{~m} . \mathrm{y}$. confirms that the N2 series of this region can be equated to the Gauss normal epoch $[7,8]$. Flow 4 occurs just below 
Table 1

Potassium-argon dates on whole rock sample of lavas from the Jokuldalur region of northeastern Iceland.

\begin{tabular}{|c|c|c|c|c|c|c|}
\hline Sample No. & $\mathrm{K}(\%)$ & $\begin{array}{c}{ }^{40} \mathrm{Ar}^{*} / 40 \mathrm{~K} \\
\times 10^{-4}\end{array}$ & $\begin{array}{l}\text { Per cent } \\
\text { atm. } 40 \mathrm{Ar}\end{array}$ & $\begin{array}{l}\text { Calculated } \\
\text { age (m.y.) }\end{array}$ & Polarity & Flow \\
\hline GA 1480 & $\begin{array}{l}0.252 \\
0.253\end{array}$ & $\begin{array}{l}\text { (1) } 0.968 \\
\text { (2) } 0.923 \\
\text { (3) } 0.919\end{array}$ & $\begin{array}{l}60.4 \\
71.3 \\
54.8\end{array}$ & $\begin{array}{l}1.66 \pm 0.07 \\
1.58 \pm 0.05 \\
1.57 \pm 0.05\end{array}$ & $\mathrm{~N}(\mathrm{R} 1)$ & 17 \\
\hline GA 1479 & $\begin{array}{l}0.505 \\
0.505\end{array}$ & 1.273 & 79.5 & $2.17 \pm 0.10$ & $\mathrm{R}(\mathrm{R} 1)$ & 14 \\
\hline GA 1477 & $\begin{array}{l}0.136 \\
0.135\end{array}$ & $\begin{array}{l}\text { (1) } 1.228 \\
\text { (2) } 1.299\end{array}$ & $\begin{array}{l}87.1 \\
90.4\end{array}$ & $\begin{array}{l}2.10 \pm 0.2 \\
2.22 \pm 0.2\end{array}$ & $\mathrm{R}(\mathrm{R} 1)$ & 11 \\
\hline GA 1476 & $\begin{array}{l}0.113 \\
0.112\end{array}$ & 1.466 & 92.5 & $2.51 \pm 0.25$ & $N(N 2)$ & 9 \\
\hline GA 1473 & $\begin{array}{l}0.388 \\
0.390\end{array}$ & $\begin{array}{l}\text { (1) } 1.816 \\
\text { (2) } 1.816\end{array}$ & $\begin{array}{l}80.5 \\
81.0\end{array}$ & $\begin{array}{l}3.10 \pm 0.10 \\
3.10 \pm 0.10\end{array}$ & $\mathrm{~N}(\mathrm{~N} 2)$ & 4 \\
\hline
\end{tabular}

$\lambda_{\mathrm{e}}=0.585 \times 10^{-10} \mathrm{yr}^{-1}, \lambda_{\beta}=4.72 \times 10^{-10} \mathrm{yr}^{-1}, 40_{\mathrm{K}}=1.19 \times 10^{-2}$ at $\%$.

three reversely magnetized lavas which are present at about the middle of the N2 series. The tops of the lower two reversed flows show little weathering and this suggests that the three lavas were erupted relatively quickly. In other parts of this region of Iceland one or more intercalated flows occur in a similar stratigraphic position [9]. From the date cn flow 4 we conclude that the reversed lavas are a little younger than $3.10 \pm$ $0.1 \mathrm{~m} . \mathrm{y}$. Doell et al. [7] and Dalrymple [12] reported an age of $3.06 \pm 0.1 \mathrm{~m}$.y. for a reversely magnetized lava from Mammoth Lakes, California. From their data they have postulated a short period of reversed polarity, called the Mammoth event. The present result from Iceland lends strong support to the reality of this short period reversal of the geomagnetic field in the Gauss normal polarity epoch.

A sample from flow 9 near the top of the N2 series yields a $\mathrm{K}-\mathrm{Ar}$ date of $2.51 \pm 0.25 \mathrm{~m} . \mathrm{y}$., which is consistent with the date of $2.5 \pm 0.1 \mathrm{~m}$.y. given for the boundary between the Gauss normal and Matuyama reversed epochs [8]. This particular basalt was slightly altered and hence the age is a minimum value.

An attempt was made to measure the age of a sample from flow 11, the lowest flow of the R1 reversed epoch, even although this basalt contained about $5 \%$ of altered, fine grained, intersertal material, probably devitrified glass. The duplicate determinations agree at $2.15 \pm 0.2 \mathrm{~m} . \mathrm{y}$., the high uncertainty being due to the low proportion of radiogenic argon. This date almost certainly is too young when the position of the sample in the sequence is considered; probably radiogenic argon has been lost by diffusion from the altered intersertal material. Flow 14, a very fresh basalt, with about $10 \%$ of unaltered isotropic glass, yields a date of $2.17 \pm 0.1 \mathrm{~m} . \mathrm{y}$. The measured age agrees well with that expected from the position of the sample in the sequence, and it serves to confirm that the specimen from flow 11 has indeed lost radiogenic argon.

Flows 16 and 17 are regarded as normally magnetized laves in the $\mathrm{R} 1$ (Matuyama) reversed epoch. Unfortunately in northeastern Iceland the upper part of the R1 series is not well represented in continuous sections. The presence of two normally magnetized flows between which occurs a lava of apparent reversed polarity in this sequence suggests that two brief intervals of normal polarity may be represented, an opinion shared with Icelandic geologist Thorleifur Einarsson [13]. A sample from the upper normal polarity flow 17 yields a date of $1.60 \pm 0.05 \mathrm{~m} . \mathrm{y}$., which is considered to be a very reliable date as the rock was quite free of alteration. No sample was available from flow 16 for dating. This older flow with normal polarity possibly may be correlated with the Olduvai normal event, dated at about 1.9 to $2.0 \mathrm{~m} \cdot \mathrm{y} \cdot[6,14,15]$. Clearly the upper normally magnetized flow gives a date too young to be correlated with the Olduvai event, and may indicate another short interval of normal polarity at about $1.60 \mathrm{~m} . \mathrm{y}$. in the $\mathrm{R} 1$ (Matuyama) reversed epoch. We tentatively propose the name Gilsá for this event, after a small tributary of the Jokulsa River in northeast Iceland. Further detailed work obviously is necessary to substantiate this inference. If the correlations are correct then they indicate that the time interval between successive lava flows in this region has increased considerably; such a conclusion is consistent with the geology. 
The present study clearly shows that the correlations previously made of the Graue Stufe sequences of Iceland with the geological time scale by means of paleomagnetic stratigraphy are correct. The results also provide additional evidence that both the main polarity epochs and the short period events are of worldwide synchronism.

\section{GEOLOGICAL IMPLICATIONS}

In Iceland glacial intercalations, mainly tillites, occur in nearly all sections of the Pliocene-Pleistocene Graue Stufe. Individual intercalations often can be followed over considerable distances. The tillites are found from about the middle of the N2 (Gauss) normal polarity epoch upward (fig. 1). Generally the older glaciations have not eroded deep valleys in the basalts in contrast to the more recent glaciations. This suggests that the tillites are ground moraines from extensive ice sheets rather than moraines from small localized glaciers.

The oldest glacial intercalation in the Graue Stufe in the Jokkuldalur region occurs just below the reversed polarity lavas of the Mammoth event, and immediately above the basalt dated at $3.10 \pm 0.1 \mathrm{~m} . \mathrm{y}$. Hence, widespread glaciation in Iceland appears to have commenced about 3.0 m.y. ago. Undoubtedly glaciation began in Iceland somewhat earlier than in regions of lower latitude. In keeping with this view, Evernden and Curtis [16] have estimated from the few relevant isotopic dates available that the Donau glaciation of Europe occurred about 1 m.y. ago.

Our data from Iceland may be of some importance with respect to the age of the PliocenePleistocene boundary. Flint [17] pointed out that two different definitions of this boundary are in use, one based on evolutionary changes of organisms, the other based on climatic change. In the latter definition the base of the Pleistocene is equated to the time at which a general cooling occurred from the more equable Pliocene climate. As a result of this cooling extensive areas became glaciated, particularly in high latitudes. In the Jökuldalur area of Iceland our results show that glaciation began about $3 \mathrm{~m} . \mathrm{y}$. ago, which suggests that the Pliocene-Pleistocene boundary, based on the climatic definition, may be as old as this. Other workers have also advanced the possibility that the Pleistocene is of considerably longer duration than has been previously thought $[17,18]$.

When agreement has been reached on an ap- propriate definition of the Pliocene-Pleistocene boundary, and when reliable physical measurements of its age have been made, correlation of this boundary throughout the world would be possible in igneous rocks by using paleomagnetic and isotopic dating methods.

The average frequency of extrusion of lavas in the Jokuldalur area may be estimated by dividing the duration of a paleomagnetic epoch by the number of lavas present in the epoch. Such a calculation indicates a mean interval of about 40000 years between successive outpourings. Red boles, produced by weathering, commonly are developed on top of the lavas, also suggesting that eruptions occurred at relatively long intervals.

\section{APPENDIX}

For details of locality of the samples see Wensink $[5,9]$.

GA 1473 (flow 4). Tholeiitic basalt consisting of plagioclase, clinopyroxene, iron oxide and 1 to $2 \%$ of intersertal pale brown, isotropic glass. Average grain size 0.1 to $0.2 \mathrm{~mm}$. The rock is free of alteration.

GA 1476 (flow 9). Tholeiitic basalt with phenocrysts of augite and less common plagioclase and olivine set in an intergranular groundmass of the same minerals and iron oxide. Intersertally about $3 \%$ of devitrified glass. Plagioclase shows incipient alteration. Grain size of groundmass averages 0.1 to $0.2 \mathrm{~mm}$.

GA 1477 (flow 11). Tholeiitic basalt similar to GA 1476 , but with 5 to $10 \%$ of imperfectly crystallized brown material which is probably devitrified glass.

GA 1479 (flow 14). Tholeiitic basalt similar to GA 1476 , but containing $10 \%$ of pale brown, isotropic glass which shows no sign of devitrification.

GA 1480 (flow 17). Tholeiitic basalt similar to GA 1473. About $2 \%$ of pale brown isotropic glass occurs intersertally. Plagioclase averages about $0.2 \mathrm{~mm}$, pyroxene about $0.05 \mathrm{~mm}$. The rock is very fresh.

\section{REFERENCES}

[1] H. Pjetursson, Om islands geologie, Thesis, Copenhagen (1905) 
[2] T. Einarsson, Magneto-geological mapping in Iceland with the use of a compass, Phil. Mag. Suppl. 6 (1957) 232.

[3] M.G. Rutten and H. Wensink, Paleomagnetic dating, glaciations and the chronology of the Plio-Pleistocene in Iceland, Int. Geol. Congr., XXI Sess., Norden, Part IV (1960) 62

[4] M. G. Rutten and H. Wensink, Structure of the Central Graben of Iceland, Int. Geol. Congr., XXI Sess., Norden, Part XVIII (1960) 81.

[5] H. Wensink, Secular variation of earth magnetism in Plio-Pleistocene basalts of eastern Iceland, Geol. Mijnbouw 43 (1964) 403.

[6] A. Cox, R. R. Doell and G. B. Dalrymple, Quaternary paleomagnetic stratigraphy, in: The Quaternary of the United States (Princeton University Press, 1965) p. 817.

[7] R. R. Doell, G. B. Dalrymple and A.Cox, Geomagnetic polarity epochs: Sierra Nevada data 3, J. Geophys. Res. 71 (1966) 531.

[8] I. McDougall and H. A. Allsopp, Isotopic dating of the Newer Volcanics of Victoria, Australia, and geomagnetic polarity epochs, in press.

[9] H.Wensink, Paleomagnetic stratigraphy of younger basalts and intercalated Plio-Pleistocene tillites in Iceland, Geol. Rundsch. 54 (1964) 364.

[10] A. Cox, R. R. Doell and G. B. Dalrymple, Reversals of the earth's magnetic field, Science 144 (1964) 1537.

[11] I. McDougall, Potassium-argon ages from lavas of the Hawaiian Islands, Geol. Soc. Am. Bull. 75 (1964) 107;

I. McDougall, Precision methods of K-Ar isotopic age determination on young rocks, in: Methods and techniques in geophysics, vol. II (Wiley, London, 1966).

[12] G.B.Dalrymple, Cenozoic chronology of the Sierra Nevada, California, Univ. Calif. Publ. Geol. Sci. 47 (1964) $41 \mathrm{pp}$.

[13] Thorleifur Einarsson, private communication.

[14] C.S. Gromme and R L. Hay, Magnetization of Bed I, Olduvai Gorge, Tanganyika, Nature 200 (1963) 560.

[15] F.H. Chamalaun and I. McDougall, Dating geomagnetic polarity epochs in Reunion, in press.

[16] J. F. Evernden and G. H. Curtis, The potassiumargon dating of Late Cenozoic rocks in East Africa and Italy, Curr. Anthropol. 6 (1965) 343.

[17] R.F. Flint, The Pliocene-Pleistocene boundary, Geol. Soc. Am. Spec. Paper 84 (1965) 497.

[18] J. F. Evernden, D. E. Savage, G. H. Curtis and G. T. James, Potassium-argon dates and the Cenozoic Mammalian chronology of North America, Am. J. Sci. 262 (1964) 145. 